\title{
8
}
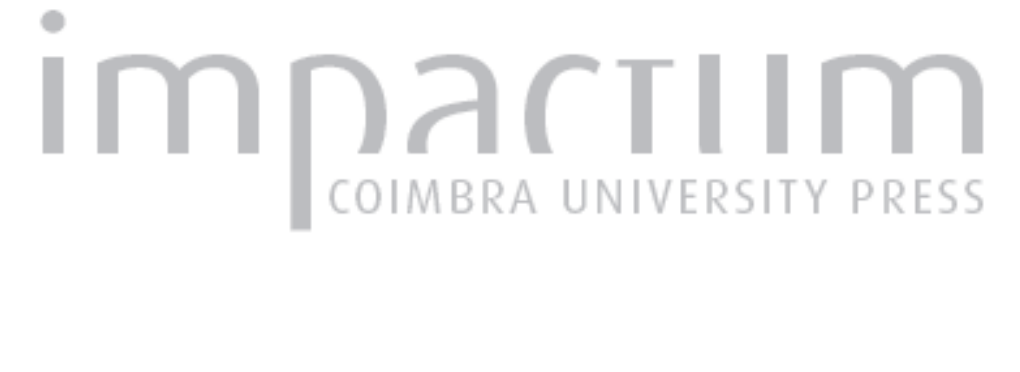

\section{Quaternary evolution of the Serra do Marão and its consequences in the present dynamics}

\author{
$\begin{array}{ll}\text { Autor(es): } & \begin{array}{l}\text { Pedrosa, António de Sousa; Marques, Bernardo Serpa; Martin } \\ \text { Sousa, José Henrique }\end{array} \\ \text { Publicado por: } & \text { Associação Portuguesa de Riscos, Prevenção e Segurança }\end{array}$ \\ URL \\ persistente: \\ URI:http://hdl.handle.net/10316.2/36221 \\ DOI: \\ DOI:http://dx.doi.org/10.14195/1647-7723_14_4 \\ Accessed : $\quad$ 26-Apr-2023 15:52:23
}

A navegação consulta e descarregamento dos títulos inseridos nas Bibliotecas Digitais UC Digitalis, UC Pombalina e UC Impactum, pressupõem a aceitação plena e sem reservas dos Termos e Condições de Uso destas Bibliotecas Digitais, disponíveis em https://digitalis.uc.pt/pt-pt/termos.

Conforme exposto nos referidos Termos e Condições de Uso, o descarregamento de títulos de acesso restrito requer uma licença válida de autorização devendo o utilizador aceder ao(s) documento(s) a partir de um endereço de IP da instituição detentora da supramencionada licença.

Ao utilizador é apenas permitido o descarregamento para uso pessoal, pelo que o emprego do(s) título(s) descarregado(s) para outro fim, designadamente comercial, carece de autorização do respetivo autor ou editor da obra.

Na medida em que todas as obras da UC Digitalis se encontram protegidas pelo Código do Direito de Autor e Direitos Conexos e demais legislação aplicável, toda a cópia, parcial ou total, deste documento, nos casos em que é legalmente admitida, deverá conter ou fazer-se acompanhar por este aviso.

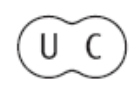




\section{territorium}




\section{QUATERNARY EVOLUTION OF THE SERRA DO MARÃO AND ITS CONSEQUENCES IN THE PRESENT DYNAMICS}

António de Sousa Pedrosa, Bernardo Serpa Marques, Bruno Martins, José Henrique Sousa Faculdade de Letras, Universidade do Porto aspedros@gmail.com

\section{RESUMO}

Situada no Norte de Portugal, a Serra do Marão faz parte de um conjunto orográfico que separa a área montanhosa de Entre Douro e Minho da área planáltica de Trás-os-Montes. As características do tempo nas épocas mais frias do Quatemário foram muito importantes no que respeita aos processos morfogenéticas, que actuaram sobre as suas vertentes, criando depósitos que então as regularizaram e que hoje condicionam a dinâmica actual.

Palavras chave: Quatemário, depósitos periglaciares, dinâmica de vertentes, ravinas, deslizamentos.

\section{ABSTRACT}

Localised in the north of Portugal, Serra do Marão is part of a mountainous range that separates the mountains of Entre Daro e Minho from the plateaux of Trás-os-Montes. Weather characteristics of Quatemary coldest times were very important in terms of monphogenetic processes, which acted on its slopes, creating deposits that, nowadays, are conditioning the present dynamics.

Key words: Quatemary, periglacial deposits, slope dynamics, gullies, landslides.

\section{RÉSUMÉ}

Située dans le nord du Portugal, la Serra do Marão fait partie de l'ensemble orographique qui sépare les hauteurs de l' Entre Douro et Minho des plateaux du Trás-os-Mbntes. Les caractéristiques des temps froids du Quatemaire ont été très importantes en ce qui conceme les processus monghogénétiques existants sur les versants, aujard'hui conditionnant la dynamique actuelle.

Mbts clé: Quatemaire, dépôts périglaciaires, dynamique de versants, ravins, glissements. 


\section{Introduction}

The Serra do Marão (as it is called locally) is a mountainous massif situated in the North of Portugal formedmainly of Palaeozoic structures. It is strongly marked by the Hercynian orogeny, which is responsible for a large number of faults and fractures. Neo-tectonic phenomena, which are quite cormon in northern Portugal, influenced this stnucture and created new faults whichmade the monchostnucture of this area even more complex.

The Mbrão is part of a mountainous range with a north-sath direction and is therefore parallel to the At lantic coast, whichexplains the heavy rainfall on the slopes tumed to the west in contrast to a much lower precipitation on the slopes facing the east.

Drring the Quatemary the action of the cold weather was very important in terms of the morphogenetic processes that acted on the slopes. On the one hand, the deposits regularised the slopes; on the other, they conditioned the present dynamics, as will be demonstrated in this paper.

\section{Geamorphologic features}

The Serra do Marão is one of the most impressive topographic structures that can be singled at in the vast orographic range that separates the northwest of Portugel from theplateaux of Trás-os-Mbites (Fig.1) . It is one of a series of mountain ranges that are traditionally seen as a whole: the mountainous range that separates Minho from Trás-os-Mbntes, the tho most daracteristic regions innorthem Portugel. Starting from the frontier of Galicia andmoving sathwards several mountain ranges are to be found: Peneda (1373 m), Gerês (1300 m) , Larouco (1527 m) , Cabreira (1262 m),
Alvão (1285 m) and Marão (1416 m) . The latter borders on the Douro valley. Still another mountain range can be added to the list - Mbntemuro (1381 m) lat it lies sath of the river Darro. The highest points in northem Portugel are to be faund in this range.

This group of mountain ranges and elevated plateaux constitute (not only on accant of their height, lat also of their laulk) an dostacle which determines a more or less rapid transformation in the Atlantic character of the landscapes; because of that it is cormonly termed condensation barrier. The Merão is situated in one of the areas of the country with the heaviest rainfall and is simultanearsly the con that offers the strongest contrasts in terms of the distribation of temperature. These two characteristics - heavy rainfall and large temperature range - make it unique among the different/variaus Portuguese mountain ranges.

The action of tectonics is fundamental to the understanding of the formation of the Marão. The Hercynian orogeny was the main factor responsible for the uplift and folding of the metasediments of the Pre-Ordbvician, the Ordbvician and the Silurian (Fig. 2) . It was also during this orogeny that the intrusion of the different granitic rodks, whichare fandon the periphery of the mountain range, took place. These orogenic movements explain many of the fractures and faults that are still tooky important features in themonghology of the area.

In spite of the importance of the Hercynian movements in this mountain range, there is no doubt that the present-day relief forms are related with the alpine orogeny. This may have had a basically epeirogenetic action which contribated to the uplift both of the mountain ranges of the Mbrão and the Alvão. consequently, these two mountain ranges function as

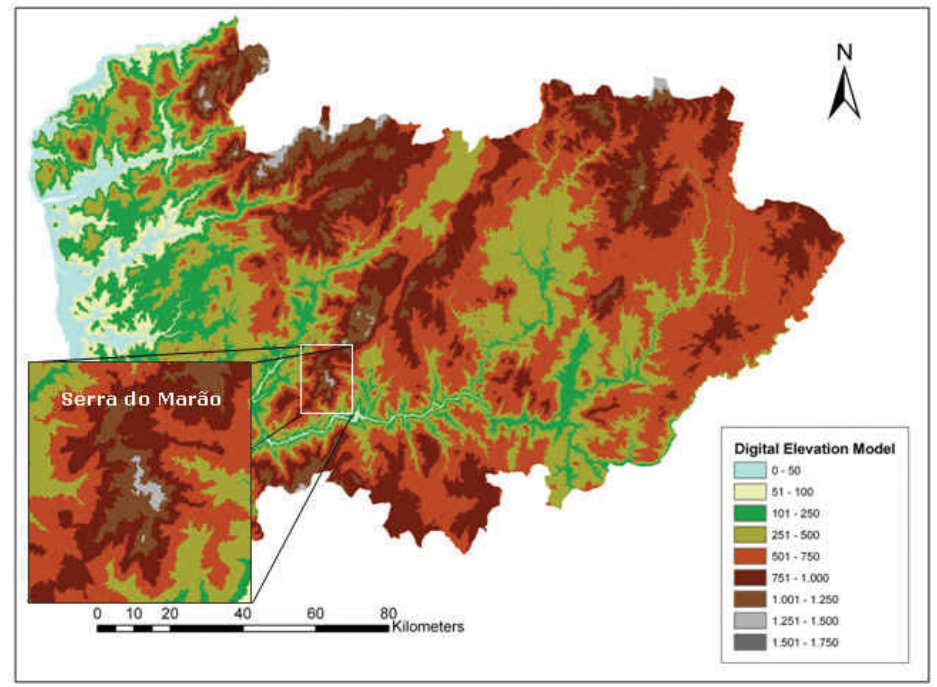

Fig.1 - Localisation of the Serra do Marão. 


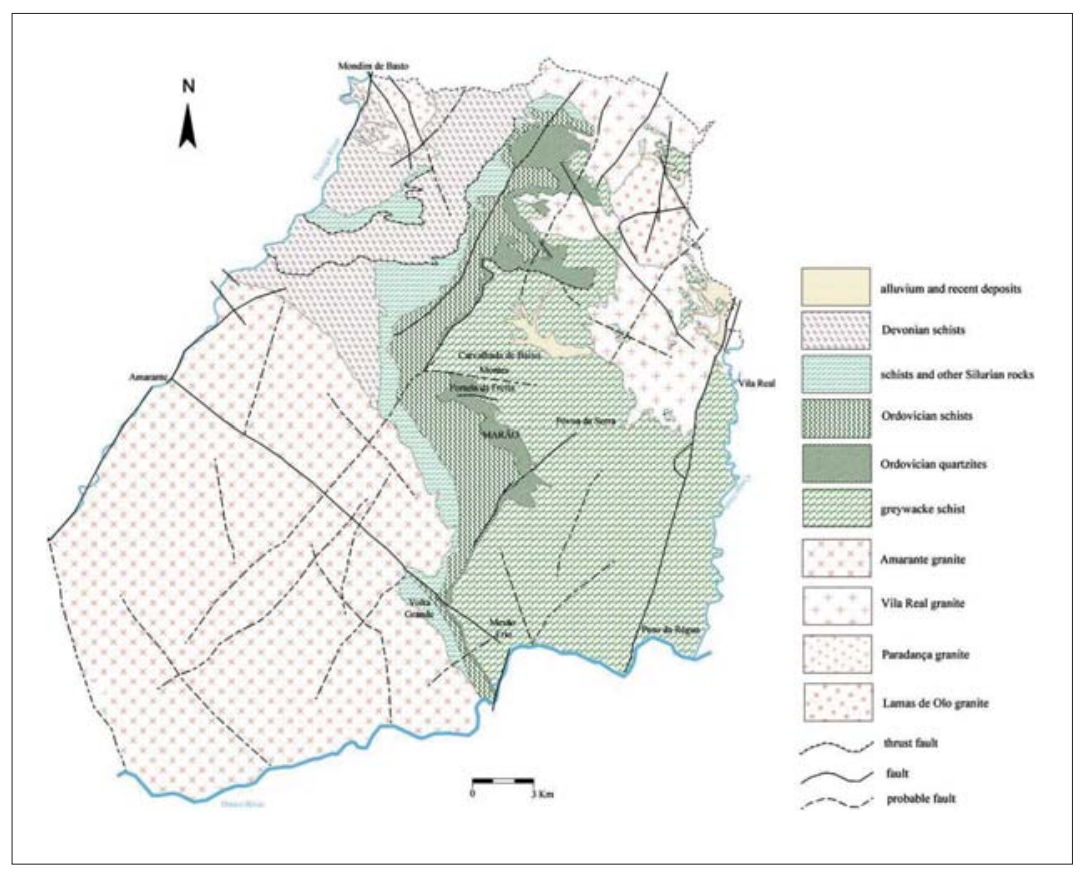

Fig. 2 - Geological sketch map of the Serra do Marão.

a horst both in relation to the group of tectonic depressions where the river Corgo flows and also to thegraben of the river Tânega. In fact, the effects of the orogeny are still to be felt and the neo-tectonics goes on acting on the present relief forms (B⿺rRoA, A., 1993, 1994). That is, tectonic action continues to transform them; thus it is a permanent risk that must be taken into account, notably whenlouilding infrastnuctures suchas roads, railways, dams and even houses.

Lithology is another important science that can explain some relief forms that are found in the Marão. The different granitic rocks, for example, are responsible for the great number of alveoli that exist there. No matter what their form and size are or the height at which they may be found, they are undabtedly related to the different types of granite. They also account for a series of microforms such as tors, block chaos, "vascas", "caneluras" which are clearly comnected with the physical, chemical and mineralogical daracteristics of these rodks.

The quartzite is a type of rodk that has a special importance in the morphology of the Marão (BrrosA, 1993) in spite of being quite often fand in the upper parts of its slopes. They are almost always found halfway up the slopes, which can be explained by the action of tectonics. Nevertheless, althagh this type of quartzite outcropping is more exposed to erosive processes de to its situation, it undabtedly contribates to the fact that thagh the inclination of the slopes is always steep the erosion acts more slowly.

In the schist areas there are several depressions of tectoric origin, lat the fundanental characteristic is in this case the regulation of the slopes by deposits related to monphogenetic processes which took place in the recent Quatemary and which were caused by the freeze/thaw action. As such, they correspond to colder climates, which are responsible for a very rapid evolution of the slopes (hotol) .

\section{Origin of the deposits}

The effects of the different monphogenetic processes which happened in the past can only be inferred from vestiges that are still doservable nowadays: the slope deposits. It is not alweys easy to interpret them. Mery have been destroyed, thus proving the existence of a powerful monphogenetic action which is related to colder climates in the carse of the Quatemary.

The deposits which were found are important evidence of the evolution of the slopes, not only at a high altitude ( low altitude in places near the coast (파며, A. , 1989, 1994C; Remo, F. \& ParrosA, A. , 1993).

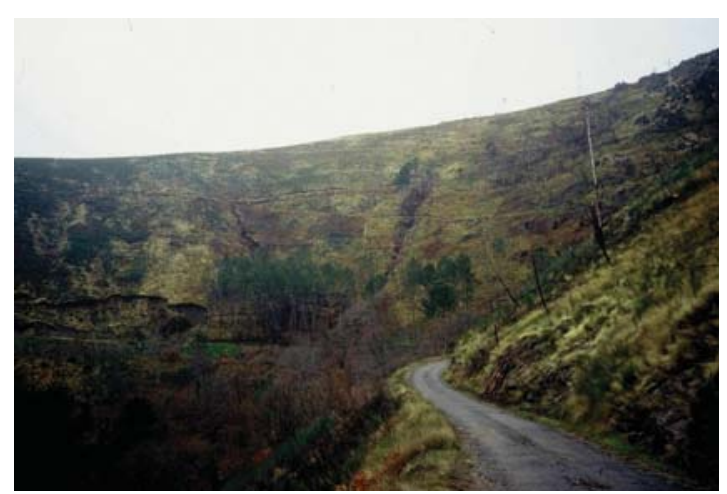

Photo 1 - Schist slope regularised by Quatemary deposits. 
The climate must then have been much more unstable than it is now with temperatures that made gelifraction in situpossible, aboveall inhigherplaces where vegetation was scarce or non-existent.

The material must have been made transported along the slopes by gel ifluction associated with a cold, dry climate (DAHAU, S. , 1973; Rerto, F. 1986; CAnEIRO, A. R. , 1986a; Prrosa, A., 1993, 1994a) ; it is passible to doserve the existence of coiffes (VAAIAS, B., 1984) . Nevertheless, the above mentioned movement must not have been carried at only by the action of ice but also by means of more or less generalised solifluctions or even by debris flous and sheet floods. The existence of palaeogul lies may lead to the conclusion that there were larger quantities of water, at least during part of the year; this would make possible the formation of gullies in the materials acamlated at the foot of the slopes by other monphogenetic processes.

Thus, the accumulation of materials along the slopes would have been necessary for the formation of such palaeogull lies but the morphogenetic processes could have been different. Absolutely necessary for their formation was, however, the altemation of drier, colder periods with others which were damper and hypothetically less cold (PErros, A. , 1993) .

The palaeasols found seem to indicate climatic fluctuations during which the existence of colder climates, hypothetically drier, contrasted withperiods of higher biostasis which might mean that there were higher quant ities of rainfall and/or milder temperatures.

The oldest deposit found in the Marão is prior to $28000 \mathrm{BP}$; it was possible to find a palaeasol that fossi lises it dating back to $28440+/-490 \mathrm{BP}$. It may correspond to the so called Wïrm II (PIrRsA, A. ,1993) . It is a deposit with heterometric characteristics, probably the result of the deposition of material transported by debris flow, althagh the possibility of its having resulted fromglacial action is not to be put aside (Fig. 3) .

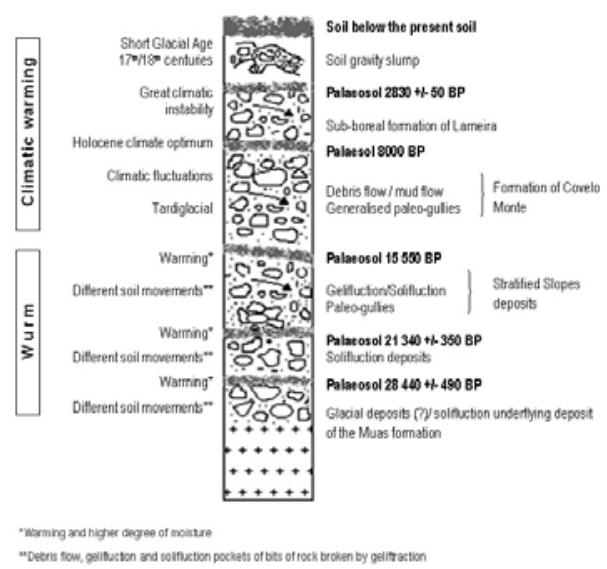

Fig. 3 - Stratigraphic colum of the superficial formations in the area of the Serra do Marão.
After the deposition of thematerials that form that depasit, the climate may have evolved; it may have become mister and the temperatures milder. This may have been responsible for the pedogenesis and the appearance of the above mentioned paleosoil. The climate must have become slightly warmer in comparison with the prior phase; this fact gave way to the pedogenesis and the colonisation of the slopes by vegetation, making them reach a dynamic equi librium.

Iater on the cl imate must have tumed cooler, which led to the formation of new slope deposits which fossilised the palaeosoil. Due to the disappearance of the vegetation, the slopes must have been more exposed to the action of fragnentationby the action of ice. The analysis of the deposits allows the dbserver to conclude that the monphogenetic processes must have been not only mass movements of the solifluction type lat also debris flows. And again comes a period of pedogenesis which dates back to around 21340 +/- 350 BP.

The next phase corresponds to the influence of the "Upper Würmian Full Glaciation" (Pleniglaciar superior Würmiano), the last glacial stage of the Pleistocene. This phase was extremely important in the evolution of the slopes in northem Portugal. In fact, there is a large number of slope deposits whose origin is to be faud in this period (Photo2). The climatemust have been cold and relatively dry because it is responsible for the gel ifraction of the rodks (DAEU, S.,

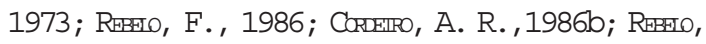
F., \& PenrosA, A., 1993).

The analysis of these deposits demonstrated that the main process of transportation along the slopes was the action of the ice-gelifluxion, funther proved by the existence of coiffes (VALADAS, 1984). Other processes such as the action of gravity are, however, not to be ignored. The study of the stratified slope depasits does not exclude the passibility of other movements such as debris flows at least in some parts of the slopes.

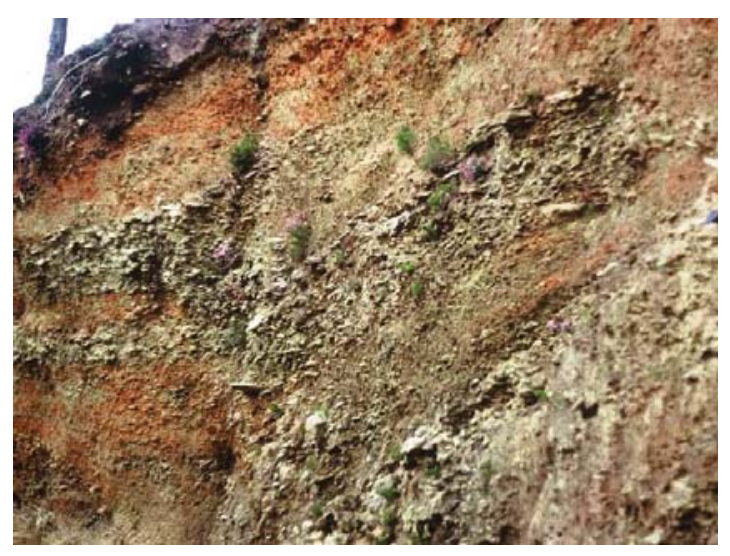

Photo 2 - Stratified slope deposit near Campanho, where it is possible to doserve paleogullies. 
With the begiming of the Tardiglacial (CAmErle, A. R. ,1990) the climate must have become warmer and the rainfall heavier, which must have altered the morphogenetic processes; now the most cormon are those connected with the nunoff and fluvial dynamics instead of those related to the action of the ice.

Parallel to the significant movement of materials which ocaurred in this period there was an extensive movement of materials resulting from prior monphogenetic processes transported more by fluvial action than by the action of the ice and solifluctions in periods of thawing. (PEDROSA, A., 1993). They contribated to the filling of the bottons of small valleys and the regularisation of a large part of the slopes (Remo, F., 1975; Rmaro, F. \& Paroca, A., 1993; PerposA, A., 1988, 1993).

However, the climate warming verified at the begiming of the Tardiglacial cannot have been linear

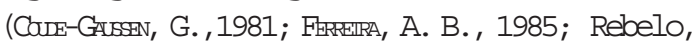
F., 1985, 1986; C CNHA, L., 1988; COPDERPO, A. R., 1986a, 1988). Today the existence of at least three moments in the last Tardiglacial are recognised (Nbw, 1966; GuUIJeN, 1962; DAvEAU, 1973, 1978), with an interphase and a recurrence of a very cold, dry phase

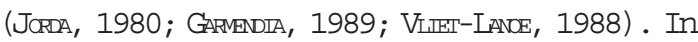
fact, it sems that the Tardiglacial is characterisedby the existence of several climatic fluctuations (Crkipr, 1990; Pectrosa, A., 1994C) ; Mhrrins, 1999) , confirmed by the features of the formation of Covelo do Mrnte. About 11000 BP a new climatic crisis must have occurred (CAnkiro, A. R. , 1990; Gurfer et al., 1978; GHNENIA, 1984); it would have led not only to the ocarrence of processes related to the action of the ice but also to general ised sol ifluctions which may have caused the remixing of deposits formed by prior processes.

It is possible to find a great heterogeneity in the Tardiglacial deposits, which depends on the exposure of the slopes, on their rodk substratum and on their inclination (ParrosA, A., 1994b; Marrlns, 1999) ; but the fundamental factor must have been the snowfall drring a part of the year and its thawing in the wermer period, which was probably the time of the heaviest rainfall. The most important processes must have been the solifluctions which were responsible for the regularisation of a great part of the slopes as well as the ocaurrence of slides especially extensive debris flows, whose marks can still be traced on the bottams of thevalleys (Hoto3).

However, it is not possible to findmature soils; the majority are entisols and are quidkly affectedby small Climatic changes. A new warming seems to have reached its peak by $8000 \mathrm{BP}$ as it was possible to find in the Mrrão some palaeosols which are contemporary with this period known as Holocene climatic qptimm.

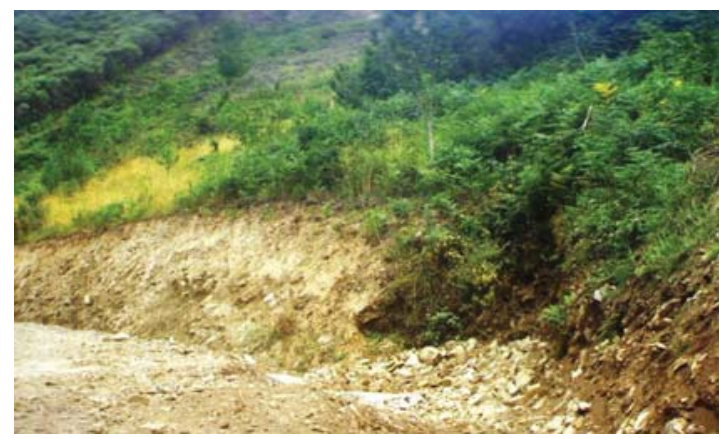

Photo 3 - Tardiglacial deposit regularising great part of the slopes of the Serra do Marão.

Around 5000 BP when the sub-Boreal period began (Gons, 1979) an increase in erosion must have taken place; this increase is probably connected with a drop in temperature as well as with some human activities, especially the luming of land to renew the vegetation and obtain new pastureland, which would increase the power of such erosion processes as runoff and splash (BrRsA, A., 1993). Solifluctions must also have ocarred in some parts of the slopes, above all inhigher places facing north. In the Marão the best example of this period is the formation of Iameira.

Gravity slumping associated with a massive congel ifraction of rodks may correspond to different generations of these forms or, at least, to the existence of different perioos which activated their formation and evolution. In the Merão they are generally found at heights superior to 700m and are sometimes associated with steep inclines, especially on shady slopes. An important phase in the origin of these forms may have been the short glacial age, which ocarred in the 17th and 18th centuries (IAurE, 1983). This process is still active nowadays in places situated on shady slopes where the bare rock appears on the surface without any soil or vegetation covering it (BRroA, A. ,1993) .

The importance of slope deposits for the present slope morphodynamics

The geomorphologic dynamics of the mountain ranges of northem Portugal is very complex since both the factors and the intervening agents as well as their interactionare diverse. Even if only the natural agents are taken into account, there is still the interaction of several factors whose relative importance varies from region to region or even fromplace to place, making the active monphogenetic processes different. It is indispensable to understand the behaviour of the fundamental climatic elements - precipitation and temperature - to explain the action of the processes which are responsible for the present evolution of the slopes, lat it is also necessary to take into account factors such as the lithology, the monphology, the biogeography and the surface formations. 


\section{The importance of the formation of gullies}

In these areas the formation of gullies is clearly conditioned by the existence of a slope deposit, which works as a regulator because there are no trees or quite often because man has acted on this terrain.

The examples that will now be given show clearly what has just been said.

In Iily 1992, on a slope near the village of Paradela do Monte (municipality of Santa Marta de Penaguião) there was a very heavy shower. Unfortunately, it is not recorded, owing to the small geographic extension of the area on which it rained and the non-existence of pluviometres, lat it is estimated to have readned values very nearly $30 \mathrm{~mm}$ while it lasted (about 1 hour) ; in consequence, two big gullies appeared (Photo 4) .

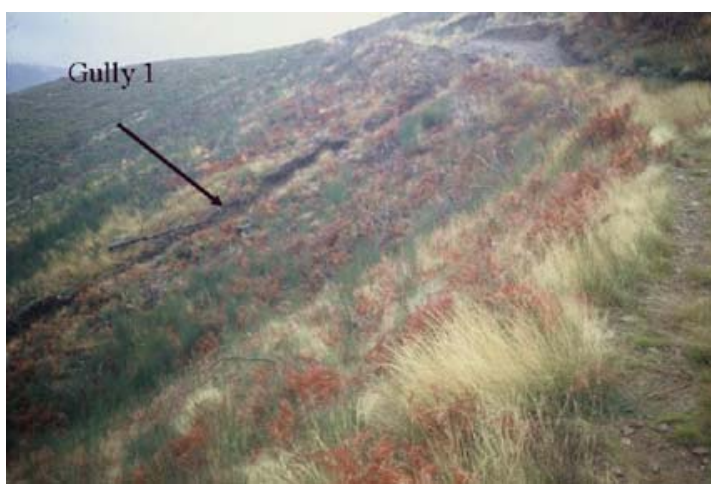

Photo 4 - Gullying in the area of Paradela do Monte.

In July 1991 there had been a fire which had completely destroyed the vegetation covering that slope. Due to the altitude and the inclination of the slope $\left(30^{\circ}\right)$, the growth of new vegetation is rather slow. The whole slope is regularised by a deposit which in some places is more than 2 meters thick. More or less in the middle of the slope two tradks were qpened on the slopes to lay a system of waterpipes. This was the background in which the slope gullying began. At first the nunoff flowed along one of the tracks and formed gullies. Later the drainage stopped flowing along the tradks, tumed in the direction of the steeper incline and formed two gullies whose depth is clearly conditioned by the depth of the deposit which regularises the slope. As soon as the water reached the schists in situ the gully thalweg could not become deeper; it became wider and the water transported the slope material which was not well consolidated. One of them deepened a pre-existing gully while the other developed at first parallel to a small valley that existed on the slope, later using only its final part; as a consequence, its thalweg became deeper.

In July 1991 there had been a fire which had completely destroyed the vegetation covering that slope. Due to the altitude and the inclination of the slope $\left(30^{\circ}\right)$, the growth of new vegetation is rather slow. The whole slope is regularised by a deposit which in some places is more than 2 meters thick. Mbre or less in the middle of the slope two tradks were qpened on the slopes to lay a system of waterpipes. This was the background in which the slope gullyying began. At first the rumoff flowed along one of the tracks and formed gullies. Later the drainage stopped flowing along the tradks, tumed in the direction of the steeper incline and formed two gull 7 ies whase depth is clearly conditioned by the depth of the deposit which regularises the slope. As soon as the water reached the schists in situ the gully thalweg cauld not become deeper; it became wider and the water transported the slope material which was not well consolidated. One of them deepened a pre-existing gully while the other developed at first parallel to a small valley that existed on the slope, later using only its final part; as a consequence, its thalweg became deeper.

In order to calculate the quantity of material transported, the length, the width and depth of the two gullies, they were measured in different sections. The results of these measurements were as follows: in one of the gullies the volume of material transported was about $465 \mathrm{~m}^{3}$ while in the other it was a bit more: about $570 \mathrm{~m}^{3}$ (Chart 1). All this material must have been transported only in the short period of time during which the rain poured down; one of the gullies has a cone of dejection just above the road (Photo 5) , formed by the coarser materials, while thematerial transported by the other crossed the road and ran down the slope into the mainbrook.

Chart 1- Dimension and Volume of material transported by thegullies.

\begin{tabular}{|l|c|c|c|c|c|c|}
\hline \multirow{2}{*}{} & \multirow{2}{*}{ Length } & \multicolumn{2}{|c|}{ Width } & \multicolumn{2}{c|}{ Depth } & $\begin{array}{c}\text { Volume of transported } \\
\text { material }\end{array}$ \\
\cline { 2 - 6 } & \multirow{2}{*}{$(\mathrm{m})$} & $\max$ & $\min$. & $\max$ & $\min$. & \multirow{2}{*}{$\left(\mathrm{m}^{3}\right)$} \\
\cline { 3 - 6 } & $(\mathrm{m})$ & $(\mathrm{m})$ & $(\mathrm{m})$ & $(\mathrm{m})$ & \\
\hline Gully 1 & 160,7 & 2,6 & 0,3 & 2,5 & 0,1 & 465,8 \\
\hline Gully 1 & 120,9 & 7,7 & 1 & 3 & 0,8 & 570,2 \\
\hline
\end{tabular}

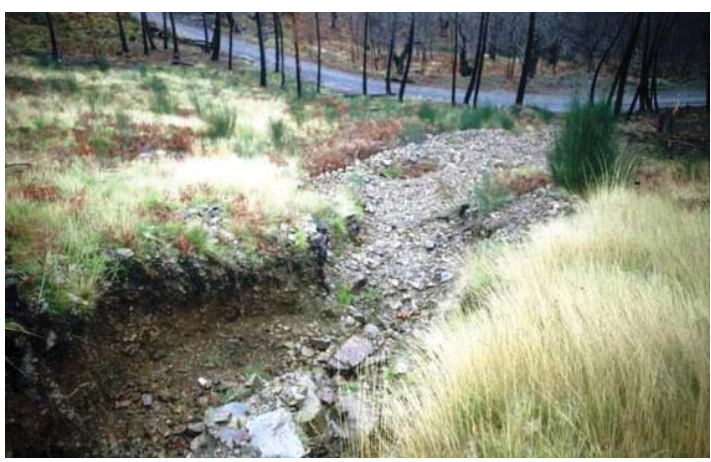

Photo 5 - Detail of the material deposited in the slope aftergullying. 


\section{The importance of mass movements}

Mass movements can have a greater or smaller complexity because they can be the result of different processes which can only be ident ified by an analysis of each individual case. Roughly speaking, they can go from the moving of small individual particles to the fall of big stones and slow or fast flows.

However, these movements cannot be explained only by adverse meteorological conditions, as neither heavy rainfalls nor all the longperiods of precipitation always give rise to soil movements. Therefore, it is necessary to look for other factors which acting together make it passible to explain the onset of the initial movement which causes the earth-flow .

In several recent studies different authors (Rme, 2001; PenRosa, 1993, 1994a, 1994b, 2001; PenRosA, Lourenço, Feiduetras, 2001 ; Pedrosa, Martins, 2001 ; Peidrosa, Bateira, Soares, 1995; Pedrosa, Marques, 1994) have tried to systematise the factors that are of greater importance for the onset of these processes in northem Portugal. Natural factors that can influence the occurrence of debris flows and mass movements have been considered up to this moment. Nevertheless, factors related to human interference are more and more frequent. Same are connected with the subdividing of estates intoplots for the building of houses, others with the building of roads and railways which imply extensive back filling (aterro) and excavation (desaterro) of land; these alter the conditions of equilibrium on the slope and are responsible for the ocurrence or, at least, for starting the initial process.

Humankind has been a geomorphological agent for $a$ long time and in this role is becoming more and more important. Human influence creates "himanised landscapes" which do not always safeguard the qperation of the natural processes and thus contribute to situations which, left to nature, might eventually happen but much, much later.

It is unquestionable that many of these movements (not only the individualised ones such as landslides, earth falls, mofflons, and so on, lat also those that act together) almost always happen after periods of heavy rainfall which leave the soil, the alterationmentles (mentos de alteração) and the slope deposits saturated or near saturation, so creating conditions to initiate the earthflow.

Besides, the infiltration resulting from the rainuater activates the underground ciralation which sometimes respects former palaeotopographies, i. e., former $\mathrm{small}$ river vall leys fossi lised by slope deposits. The water manages to tridkle between the rodk, little or not altered, and the overlying deposits. When these underground flows are strong and are associated with the water infiltrated directly from the rainfall, they cancontribate to the fluidity of the overlying deposits and, in dbing so, to create conditions for their starting a movement which often extends downstream through flows containing a higher or small ler quantity of mul.

Besides the hyotrocl imatic conditions, structural aspects both lithological and tectonic are sometimes fundamental factors, often playing an important part in that they condition the type of movement, its size and the evolution of the area affected.

qite often it is the net of faults and fractures that contributes to facil itate the alteration of the rodks and allows a more efficient infiltration of water which reaches progressively deeper levels and ends up by making the surface mass movements easier.

The geamonphological factors are the most varied and those that have more significant repercussions when connected with other factors - natural and human.

The steepness of the slope is another monphological factor of great importance for the onset of mass movements. The above mentioned authors speak of steep inclines almost always superior to $30 \%$ as being one of the monphological factors decisive for the fast evolution of the slopes and it is one of the criteria that may provide important elements for the definition of areas of potential risk.

Breaks in the slope, above all when they contribute to the increase of the incline downstream, are a local factor responsible for the worsening of the conditions of the ocarrrence of movements; because of that, they deserve a special reference.

Besides the incline, the form of the slope alsoplays an important part in the creation of conditions favarable to the development of processes of slope evolution.

Slope regulation by surface formations is undabtedly one of the factors that may contribute in a more decisive way to the development of these mass movements, which according to their characteristics can lead to movements sometimes slow sometimes fast. Thus, when the surface formation corresponds to deep alteration mantles, capable of absorbing large quantities of water, it can lead to extensive mass movements. In fact, thegreat thidkness of the alteration mantle or of the deposit favars the water infiltration; the saturation point can then be reached and the soil may begin to collapse. The great absonption power may slow down the beginning of the movement and bring about its development in stages over the course of several days.

Another frequent situation has to do with the thin slope deposits of the Quatemary, rich in argi 17 laceous material with a great capacity to absorb water, lying on rodks which are little altered and which quite often act as an efficient sliding surface. In the schist and quartzite areas of the mountain ranges in northem Portugal, this is one of the most efficient natural 
processes of slope evolution. In fact, when heavy rain falls for longperiods of time on steep slopes regularised by slope deposits, mass movements such as debris flows happen frequently.

\section{Debris flows in the Serra do Marão}

Debris flows are a frequent occurrence on the slopes of the Merão. They are related to the quantity of rainfall, the steep incl ination of the slopes and above all to the regularisation of the schist slopes by the deposits of the Quatemary which have al ready been mentioned in the first part of thispaper. In fact, it is on the discontinuity surface which coincides with the contact between the slope deposits and the bedrock that the failure ocars and the debris flowbegins.

In fact, surface formations constituted by the slope deposits of the Quatemary all low the infiltration of the rainwater that then flows through the deposit materials but above all in the surface of contact between them and the metasedimentary rocks, which owing to their impermeabi lity, lead to the acamulation and flow of the infiltratedwater. Thus, when the period of rainfall is long, the fluidity of the overlying depositsmay increase, causing the nupture.

In 1992 several debris flows occurred in consequence of a long period of precipitation (A. Pectrosa, 1993); they happened near the villages of Montes e Póvoa da Serra, whose slopes are steep and covered with trees; but the fundamental reason was the fact that they were regularised by deposits (Photos 6 and 7).

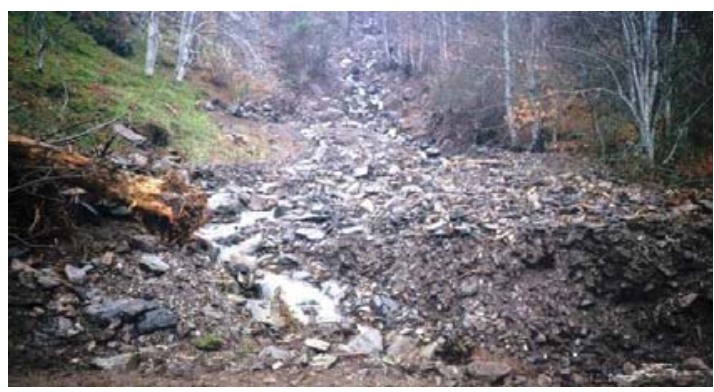

Photo 7 - Another detail of the debris flow in Póvoa da Serra.

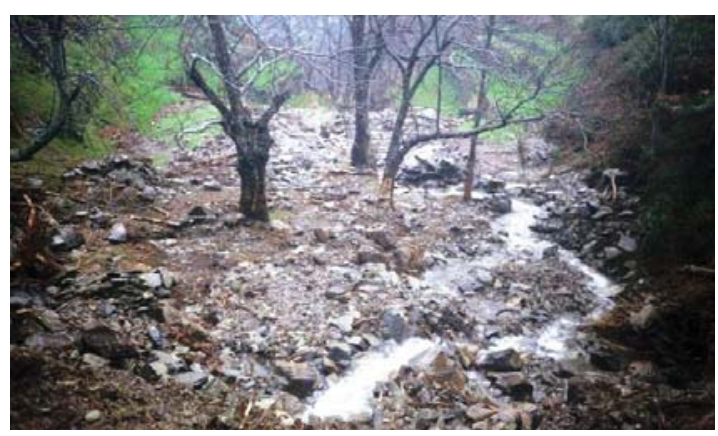

Photo 6 - Characteristics of the debris flow of Póvoa da Serra.
Later, in 1997, after a few very rainy days, some more debris flows occurred in slopes with the same characteristics as those already described. This is the case of Portal da Freita (Photo 8) and of Carvalhada de Baixo (Photo 9) both near the village of Mbntes.

Again in 2001, after a longperiod of rainfall, there were debris flows down several slopes; all of them had the same characteristics: a steep inclination and the presence of a surface formation witha thidkness of $1.5 / 2$ metres which regularises the slopes. In that same year, besides the ocarrence of debris flows in newplaces, there were also new movements in the locations of previous flows, such as the ones in Póvoa da Serra or inMbntes.

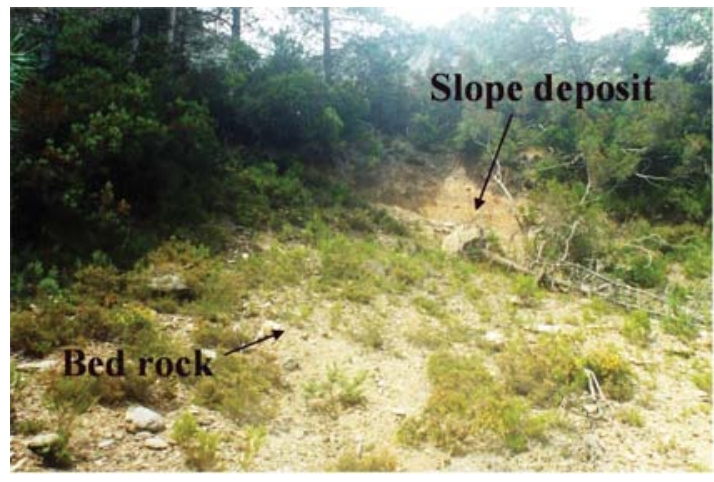

Photo 8 - Detail of the place where the debris flow of Portal da Freita began, whose failure is clearly related with the contact of the deposit with the bedrodk.

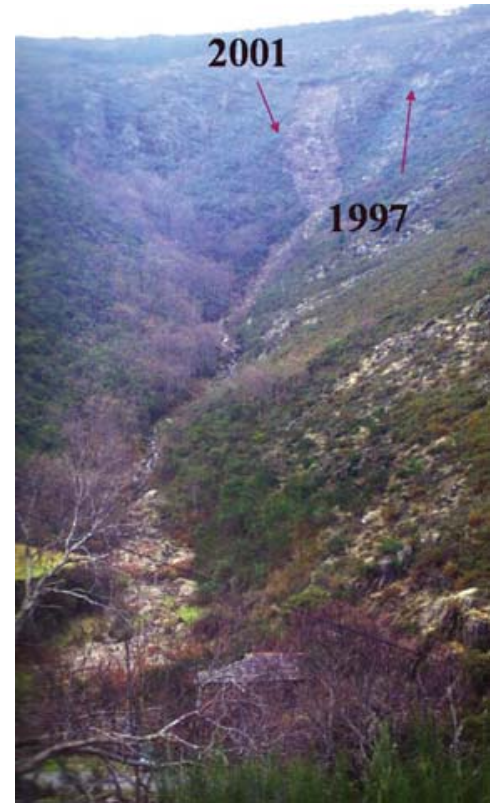

Photo 9 - Debris flow in Carvalhal de Baixo where it is passible to doserve that the place of the flow began coincides with slope are regularised by deposit. 
The one that had the most serious consequences happened place near Mesão Frio (Volta Grande) (Photo 10). It reached road no N101 (Amarante Peso da Régua) , dragging two cars that were driving along it and causing the death of one of the drivers. This example shows clearly the risk of building roads on the foot of slopes with the dharacteristics that have been described because processes of rapid change in the characteristics of the slopes often ocar in these circumstances, leading to a greater instabi i ity of the regolithmaterials that regularise the slope.

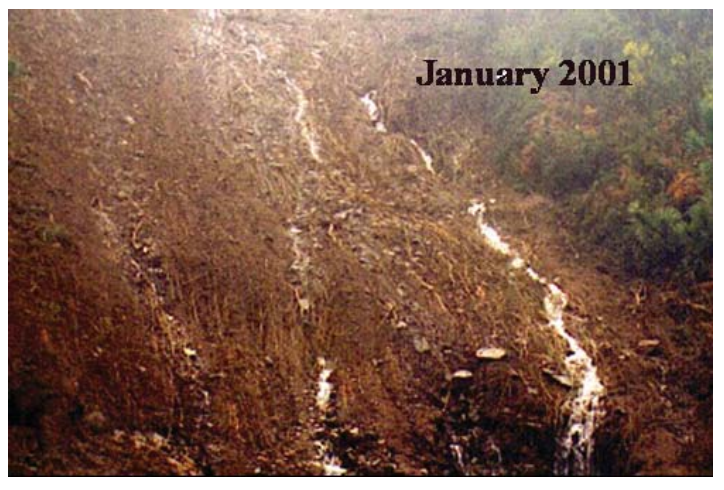

Photo 10 - Location of the occurrence of the debris flow of Volta Grande which affected road N101 and dragged two cars causing one death among the car occupants.

\section{Canclusion}

The behaviour of cl imatic elements is important for the understanding of the monphogenetic processes. The analysis of such elements cannot confine itself to the mean values because it is important to know their variation, not only during one year but also over a larger number of years, especially on account of the consequences that that variation may have on the morphogenetic processes (R Rнस्O, 1983; BRYANL, 1991; FALCARES, 1991).

Mass movements do not always coincide with the day of the heaviest rainfall; quite often they ocar on days on which the precipitation is scarce or even nonexistent. So it is indispensable to observe the pluviometric values of periods further from the day on which the movement occurred. Although there may be a relationship between the occurrence of very heavy rainfall and the occurrence of movements the prolonging of heavy rain over many days causes soil saturation (Ftafourr, 1989). Thus, in areas with large quantities of argillaceous material the relationship of heavy rainfall to earthflowmovement is not so direct, because its water absonption capacity is very high, which retards the ocarrence of the slip.

Another important factor in the dynamics of the monphogenetic processes is morphology. Thus, when one goes from steeper slopes to gentler ones, one may observe the deceleration of the erosion processes in favour of processes of acamulation of materials (Yong, 1969).

Slope inclinations have great influence on the dynamics of anly present-day monphogenetic process; therefore, it is aneverpresent factor in the analysisand understanding of the morphogenetic processes and theiraction.

On the slopes on which these flows occurred the mean incl ination varies between $30^{\circ}$ and $40^{\circ}$ which is an important element in the onset of the whole process. In some places the gradient is even higher: for example, near Póva da Serra the mean slope inclination is over $40^{\circ}$. However, near the scars in the place where the debris flow began the angle is over $60^{\circ}$.

But on the slopes of the Marão it is the fact that they are regularised by slope deposits that are very different insize that facilitates the infiltration of rainuater even on steep slopes. The water reaches quickly the plane of contact with the bedrock, which is relatively impermeable. That is where the rupture ocars which allows the debris flow to begin.

The study of the present monphogenetic processes may contribute to knowledge about the natural hazards (MMRLIN, 1987; RABEIO, 1991b, 1994; BRYANT, 1991). Knowing the elements that interact on the slopes is fundamental; they must be understood from a dynamic point of view, distinguishing between the major and theminor factors.

The geomorphologist must know as deeply as possible the combinations and ways in which these factors act. But although it is possible to map areas where landslides may take place, the forecast of the occurrence of such phenomena is based merely on a probabil ity and not on a precise indication both in time and in space.

However, the study of a growing number of cases related to specific monphogenetic processes makes it passible to get a deeper insight into the way these processes qperate, which will enable the authorities to mitigate their harmful consequences, to establish a scale of risks and draw maps showing the vulnerable areas in the landscape.

\section{Bibliography}

Brakr, E.A. (1991) - Natural Hbzards, University Press, Cambridge.

Chnziro, A. R. (1986a) - Evolução das vertentes na Serra da Freita, dissertação no âmbito das provas de Aptidão Pedagógica e Capacidade Científica à Faculdade de Letras da Universidade de Coimbra, coimbra, (policopiado). 
Conkino, A. R. (1986b) - "Nota preliminar sobre as formas e formaçoes periglaciares na Serra da Freita", cademos de Geografia, 5, coimbra, p. 161-172.

ChnErro, A. R. (1988) - "Evolução das vertentes da Serra da Freita no Quatemário recente", Cademos de Geografia, 7, Coimbra, p. 87-133.

Canziro, A. R. (1990) - "O depósito de Varzielas (Serra do Caramulo) : contribuição para o estudo do Tardiglaciar Würmiano em Portugal", Cademos de Ceografia, 9, coimbra, p. 49-60.

Caré - Gurssn, G. (1981) - "Les Serras de Peneda et do Gerês: Étude de géomorphologie", Memórias do C.E.G., 5, Iisboa.

CNä, L. (1988) - "As Serras Calcárias de CondeixaSicó-Alvaiázere. Estudo de Geomorfologia", Dissertação de Doutoramento, Faculdade de Letras da Universidade de Coimbra, Coimbra.

Danzin, S. (1973) - "Quelques exemples d'évolution quatemaire des versants au Portugal", Finisterra, 15 (VIII) : p. 5-47, C.E.G., Iisboa.

DaWrav, S. (1978) - Le périglaciaire d'altitude au Portugal, colloque sur le périglaciaire d'altitude du domaine méditerranéen et abords, Association Géographoque d'Álsace, Strasbourg, p.63-78.

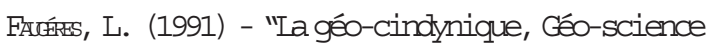
du risque", Bull. Assoc. Céographes Françaises, n³, Paris, p.179-193.

Flanduier, Jean-Claude (1989) - Les mouvements de terrainet leurprévention, Masson, Paris.

GHMNIIA, M. C. P. (1988) - "Dynamique de vegetation tardiglaciaire et holocene du Centre-Nord de l'Espagne d'après l'analyse pollinique" , Thése en Sciences, spéc. Palecécologie, de l'Thiversité d'Aix-Merseille III.

Gorre, A. (1979) - Eniviromental Change, Clarendon Press, Oxford.

Gmrn, Y. (1962) - "Néoglaciaire et Tardiglaciaire: Géochimie, Palynologie, Préhistoire", Anmales de Ceographie, 383 (IXXI) , p. 1-35.

Gminv, Y. et al. (1978) - "Les climats et les homes en Errope et en Afrique septentrional de 28000 BP à 10 $000 \mathrm{BP}^{\prime}$, Bull. Assoc. Fr. Erod. Qatem. , 4 (15) , p. 187193.
JorRA, M. (1980) - Morphogenèse et évolution des paysages dans les Alpes de Haute Provence depuis le Tardiglaciaire: facteurs naturels et facteurs anthropiques, Bull. Assoc. Céog. Fr., p. 75-81.

Lrure, E. Le Roy (1983) - Histoire du climat depuis I'anmil, Flammarion, Paris.

MhrrIN, J. (1987) - "Les risques natureis au Maroc: reflections prel iminaires, Hormage a Gerard NeurerLes milieux et les hommes dans les pays mediterranéerms", fasc 11, Études mediterranéens, Centre Intenuniversitaire d' études Mediterranéens, Poitiers, p. 2/5-290.

MarTiNS, Bruno (1999) - Estudo das formações superficiais na vertente norte da Serra do Alvão contributo para o seu conhecimento gecomorfológico, IICT, ed. Autor, 101 pp, Iisboa.

Nhw, H. (1966) - "Les regions côtières de la Galice (Espagne) : Étude gecomonphologique", Thése Lettres, Rub. Fac. Iettres, Unv. Strasbarg, Strasbarg.

PenrosA, A. S. (1989) - "A Importância do Frio na Evolução das Vertentes na área de S. Miguel-o-Anjo", Cademos de Geografia, n 8, IEG, Coimbra, 1989 p. 199-207.

Penrosa, A. S. (1993) - Serra do Marão: Estudo de geomorfologia, Dissertação de Doutoramento, Faculdade de Letras da Univiversidade. do Porto, Porto.

PEDROSA, A. S. (1994a) - Contributo para o conhecimento da dinâmca geomorfológica das serras do Norte de Portugal. O exemplo da serra do Marão, Rurália, Arouca, p. 69-90.

Penrosa, A. S. (1994b) - "As actividades humanas e os processos morfológicos. O exemplo da Serra do Merãd", Territorium, Coimbra, p. 23-34.

Paroofa, A. S. (1994C) - "O Periglaciar no Norte de Portugal: O estado actual dos conhecimentos, Periglaciarismo en la Península Ibérica, Canaria y Baleares", Granada, p. 55 - 73.

PEDROSA, A. (2001) - "Movimentos em massa e ordenamento do território", in Actas do II Seminário sobre Recursos Naturais, Ambiente e Ordenamento do Território, Vila Real , GF-7-11.

PerrosA, A. ; Mredes, B. Serpa (1994) - "Man's action and slope erosion: A case study in Tâmega Basin (1981)", Territorium, 1, coimbra, p. 23-34. 
Perrosa, A. S. et. al. (1995) - "Covelo do Gerês: Contrijuuição para o estudo dos movimentos de massa noNbrte de Portugal", Territorium, 2, coinbra, p.21-32.

PerrosA, A. S. et. al. (2001) - Metodologia para o estudo dos ravinamentos, Metodologias de Estudo de Processas de Erosão, FLUP, Porto, p. 85-98.

Pedrosa, A. S. ; Lourenço, L. ; Fejgueiras, J. (2001) "Mbvimentos em massa: exemplos ocorridos no Norte de Portugal" , Revista Técnica e Formativa da Escola Nacional de Bambeiros, Ano 5, n 17, p. 25-39.

Penrosa, A; Marrins, Bruno (2001) - "Os movimentos em massa e os depósitos de vertente em áreas metassedimentares: alguns exemplos no Norte de Portugal" , in Actas do II Seminário sobre Recursos Naturais, Ambiente e Ordenamento do Território, Vila Real, CO-161-169.

Rнвн10, F. (1975) - "Serras de Valongo: estudo de Geomorfologia", suplementos de Biblos, 9, coimbra.

Rewo, Femando (1985) - "História e Geografia Física - Reflexc̃es em tomo de um caso de intercisccipl inaridade desenvolvido por Jaime Cortesão" . Cidadania e História, Revista de História Econámica e Social, 6-7, Lisboca, Sá da Costa, p. 103-110.

Rнвно, F. (1986) - "Mbdelado periglaciar de baixa altitude em Portugal" , Cadernos de Geografia, 5, coimbra, p. 127-137.

Rmaro, F. (1991) - 'Geografia Fisica e Riscos naturais: alguns exemplos de riscos geomorfologicos em vertentes e arribas no domínio mediterrânico", Biblos, IXVII, coimbra, p. 353-371.

RसнFo, F. (1994) - "Do ordenamento do território à gestão dos riscos naturais. A importância da Geografia Física salientada através de casas seleccionados em Portugal", Tenritorium, Coimbra, p. 7-15.

Rसwo, F. (2001) - Riscos naturais e acção antrópica, Imprensa da Universidade, Coimbra.

RFBELO, F; PedrosA, A. (1993) - "Novas observações sobre depósitos relacionados com o frio na área de Valongo - S. Miguel-o-Anjo", Ell Clatemario en Espana y Portugal, volume II, Madrid, p. 501-504.

VLINILLANE, B. (1988) - Ie role de la glace de ségrégation cans les formations superficielles de l'Errque de l'O est. Processus et héritages. Thèses de Doctorat d'Etat Mens. Géographie, Univ. Paris I, tome 1 et 2, Caen, 854 pp.
VAIFDAS, Bemard (1984) - Les hautes terres du massif Central Fançais. Contribution à l'étude des morphooknamiques récentes sur versants cristallins et volcaniques, vol. I, II, Liniversitéde Paris I, Paris. 